\section{Postharvest Longevity and Responsiveness of Guava Varieties with Distinctive Climacteric Behaviors to 1-Methylcyclopropene}

\author{
R. Porat ${ }^{1,3}$, B. Weiss ${ }^{1}$, I. Zipori ${ }^{2}$, and A. Dag ${ }^{2}$
}

AdDitionAL INDEX wORDs. ethylene, ripening

Summary. The local guava (Psidium guajava) variety cultivated in Israel, named Ben Dov, emits a strong odor and suffers from a short postharvest life. To address these problems, we initiated a guava breeding program, and identified two new varieties, the pink-flesh King and the white/yellowish-flesh Omri, that have much better storage lives and emit fewer odors. Physiological characterization of their ripening process revealed that the traditional variety Ben Dov exhibited a classic climacteric behavior, whereas the new variety King had a suppressedclimacteric phenotype, and Omri was apparently nonclimacteric and did not exhibit any increases in respiration and ethylene production rates during ripening. Furthermore, differing concentrations of the ethylene action inhibitor 1 -methylcyclopropene (1-MCP) were required to inhibit ripening in the various varieties: a high $1-\mathrm{MCP}$ concentration of $500 \mathrm{~nL} \cdot \mathrm{L}^{-1}$ was required to delay ripening and to prolong postharvest storage life of the climacteric variety Ben Dov; a moderate concentration of $250 \mathrm{~nL} \cdot \mathrm{L}^{-1}$ inhibited ripening of the suppressedclimacteric variety King; and a low concentration of just $100 \mathrm{~nL} \cdot \mathrm{L}^{-1}$ was sufficient to inhibit ripening of the nonclimacteric variety Omri. The results of this study indicate that different guava varieties may pursue distinctive climacteric behaviors: the suppressed-climacteric variety and, to a greater extent, the nonclimacteric variety, have longer storage lives and are more sensitive to 1-MCP than the traditional variety.

$\mathrm{G}$ uava, which belong to the Myrtaceae family, are widely cultivated in tropical and subtropical countries and find increasing popularity all over the world (Morton, 1987); they are consumed fresh or are processed to form juices, purees, jams, and jellies (Adsule and Kadam, 1995). The fruit are very nutritious and rich in carotenoids, phenols, vitamins $\mathrm{A}$ and $\mathrm{C}$, and dietary fibers, and are known for their high antioxidant activity (Bashir and Abu-Goukh, 2003; Jimenez-Escrig et al., 2001). The fruit exude a strong odor, and are rich in volatile aroma compounds (Steinhaus et al., 2008).

The main obstacles to commercial export and marketing of fresh ripe guava are that they are highly

This research was funded by grant number 203-0731-07 from the Chief Scientist of the Ministry of Agriculture and Rural Development of Israel

This manuscript is a contribution no. 525/08 from the Agricultural Research Organization (ARO), The Volcani Center, Bet Dagan 50250, Israel.

${ }^{1}$ Department of Postharvest Science of Fresh Produce, ARO, The Volcani Center, P.O. Box 6, Bet Dagan 50250, Israel

${ }^{2}$ Department of Fruit Tree Sciences, ARO, The Volcani Center, P.O. Box 6, Bet Dagan 50250, Israel ${ }^{3}$ Corresponding author. E-mail: rporat@volcani.agri. gov.il. perishable and emit a strong odor that is not always acceptable in marketing chains. The changes that occur ing, external color change from green to yellow, and metabolic changes in biochemical composition (Bashir and Abu-Goukh, 2003; Brown and Wills, 1983; Jain et al., 2003; Mercado-Silva et al., 1998). Moreover, guava fruit are very delicate and vulnerable to bruising and mechanical injuries; they are also highly susceptible to chilling injuries and diseases (Gonzales-Aguilar et al., 2004; Kader, 2002).

According to their respiratory patterns and ethylene production rates during ripening, fruit and vegduring ripening include rapid soften- etables are classified into two major groups, known as "climacteric" and "nonclimacteric" (Baile, 1964). Climacteric fruit are those whose ripening process is accompanied by peaks in respiration and ethylene production rates, whereas nonclimacteric fruit do not exhibit such increases (Giovannoni, 2001). In climacteric fruit, ethylene plays a key role in governing the physiological and biochemical changes that occur during ripening, whereas in no-climacteric fruit, ethylene is not necessary for the coordination and completion of the ripening process (Barry and Giovannoni, 2007; Lelievre et al., 1997). In addition to these classical categorizations, it was reported that some varieties of plum (Prunus salicina), apple (Malus $\times$ domestica), and pear (Pyrus serotina), exhibit a "suppressed-climacteric phenotype," i.e., they produce ethylene during the later stages of ripening, but at lower levels than normal climacteric types; they also exhibit a reduced respiratory behavior (Abdi et al., 1997, 1998; Downs et al., 1991).

Guava fruit are usually classified as climacteric: most of the commercial varieties exhibit increases in respiration and ethylene production rates during ripening (Brown and Wills, 1983; Mercado-Silva et al., 1998; Singh and Pal, 2008a). In contrast, some guava varieties were considered nonclimacteric because they exhibited constant rates of respiration during ripening (Baile and Barcus, 1970). Studies of the ripening behavior of 'Pedro Sato', a common red-pulp variety cultivated in Brazil, revealed that it had an unusual climacteric behavior: the maximum respiratory activity and ethylene production rates were observed only after the fruit had ripened, and exogenous application of ethylene did not

\begin{tabular}{llll}
\hline $\begin{array}{l}\text { Units } \\
\text { To convert U.S. to SI, } \\
\text { multiply by }\end{array}$ & U.S. unit & SI unit & $\begin{array}{l}\text { To convert SI to U.S., } \\
\text { multiply by }\end{array}$ \\
\hline 29,574 & $\mathrm{fl} \mathrm{oz}$ & $\mu \mathrm{L}$ & $3.3814 \times 10^{-5}$ \\
29.5735 & $\mathrm{fl} \mathrm{oz}$ & $\mathrm{mL}$ & 0.0338 \\
3.7854 & gal & $\mathrm{L}$ & 0.2642 \\
25.4 & inch $(\mathrm{es})$ & $\mathrm{mm}$ & 0.0394 \\
18.0636 & inch ${ }^{3} / \mathrm{ton}$ & $\mu \mathrm{L} \cdot \mathrm{kg}^{-1}$ & 0.0554 \\
0.4536 & $\mathrm{lb}$ & $\mathrm{kg}$ & 2.2046 \\
4.4482 & $\mathrm{lbf}$ & $\mathrm{N}$ & 0.2248 \\
28,350 & $\mathrm{oz}$ & $\mathrm{mg}$ & $3.5274 \times 10^{-5}$ \\
1 & $\mathrm{ppb}$ & $\mathrm{nL} \cdot \mathrm{L}^{-1}$ & 1 \\
1 & $\mathrm{ppm}$ & $\mathrm{mg} \cdot \mathrm{kg}^{-1}$ & 1 \\
$\left({ }^{\circ} \mathrm{F}-32\right) \div 1.8$ & ${ }^{\circ} \mathrm{F}$ & ${ }^{\circ} \mathrm{C}$ & $\left(1.8 \times{ }^{\circ} \mathrm{C}\right)+32$
\end{tabular}


stimulate fruit ripening (Azzolini et al., 2005).

1-Methylcyclopropene (1-MCP) is an ethylene antagonist that interacts with the ethylene receptors and thereby prevents its action (Sisler and Serek, 1997). Application of 1-MCP is widely used to extend postharvest storage lives and to prevent spoilage of horticultural produce (Blankenship and Dole, 2003; Watkins, 2006). 1-MCP is used effectively to delay ripening in climacteric fruit but, nevertheless, it also affects ripening processes in nonclimacteric fruit (Huber, 2008); for example, exposure to 1-MCP increased storability and shelf life of climacteric and nonclimacteric plum varieties (Abdi et al., 1998; Martinez-Romero et al., 2003). In guava, 1-MCP efficiently delayed ripening in 'Allahabad Safeda', a classic climacteric-type guava variety from India, and 'Pedro Sato', a Brazilian variety with an unusual climacteric behavior (Bassetto et al., 2005; Singh and $\mathrm{Pal}, 2008 \mathrm{~b}$ ).

'Ben Dov', the main guava variety cultivated in Israel, is very popular and tasty, but emits a strong odor and suffers from a short postharvest storage life. To overcome these limitations, which restrict commercial export and trading of guava fruit, we initiated a guava breeding project and developed new varieties that have much better storage lives and emit fewer odors than the traditional locally grown variety (Zipori et al., 2006). Two of these new varieties are King, a red-flesh variety that is a hybrid of Brazilian and Mexican varieties, and Omri, a white/yellowish flesh variety that is a hybrid of Mexican and Thai varieties (Zipori et al., 2006). In the present study, we examined the postharvest storage longevity and the ripening physiology of the 'King' and 'Omri' guava compared with 'Ben Dov', and found that they exhibit distinctive climacteric behaviors and differ in their postharvest longevity and responsiveness to 1-MCP.

\section{Materials and methods}

Plant material and StORAge CONDITIONS. Guava fruit were harvested at the light-green stage (hue angle $\approx 110^{\circ}$ ) from a commercial orchard of 5-year-old trees, and were used on the day of harvest. For evaluation of their postharvest ripening physiology, the fruit were held at a constant temperature of $20{ }^{\circ} \mathrm{C}$ for up to $10 \mathrm{~d}$. For postharvest storage experiments, the fruit were stored at $10^{\circ} \mathrm{C}$ for $10 \mathrm{~d}$ and then transferred to shelf life conditions at $20{ }^{\circ} \mathrm{C}$ for an additional $3 \mathrm{~d}$. Each treatment comprised three boxes, each containing 16 fruit, and all experiments were repeated three times.

Respiration AND ETHYLENE PRODUCTION. Individual fruit were sealed at $\mathrm{l}$-d intervals in 0.5 - $\mathrm{L}$ glass chambers equipped with a rubber serum cap. After $l \mathrm{~h}$ of incubation at $20{ }^{\circ} \mathrm{C}$, gas samples were withdrawn from the sealed chambers into gastight syringes and injected into gas chromatographs for the determination of respiration and ethylene evolution rates. The carbon dioxide $\left(\mathrm{CO}_{2}\right)$ concentrations were determined with a gas chromatograph (Packard 7500; Hewlett-Packard, Bloomington, IL) equipped with a CTR-I packed column (Alltech Biotechnology, Guelph, $\mathrm{ON}$, Canada) and a thermal conductivity detector. Ethylene concentrations were determined with a gas chromatograph (Varian 3300; Varian, Palo Alto, CA) equipped with a Carbowax $20 \mathrm{M}$ column (Agilent Technologies, Santa Clara, CA) and a flame ionization detector. In both cases, helium was used as the carrier gas. The data presented are means $\pm \mathrm{SE}$ from five replicate samples taken from different individual fruit. The same individual fruit were measured throughout the experiment.

Firmness Determination. For firmness measurements, unpeeled fruit were punctured to a depth of $5 \mathrm{~mm}$ with a $6-\mathrm{mm}$ probe at both sides of their equatorial axes, and the maximum force required to penetrate the fruit surface was determined with a force gauge (model FG-20GK; Lutron, Taipei, Taiwan). Five fruit were used for each measurement, and the results are expressed in Newtons.

Color measurement. Peel color was evaluated by measuring the hue angles with a Chromo Meter (model CR-300; Minolta, Osaka, Japan) according to McGuire (1992). A hue angle of $120^{\circ}$ represents green color, whereas $90^{\circ}$ represent yellow.

1-MCP Treatments. On the day of harvest, fruit were placed for $16 \mathrm{~h}$ in sealed $250-\mathrm{L}$ plastic tanks in the presence of air (control) or various concentrations $(100,250$, and
$500 \mathrm{~nL} \cdot \mathrm{L}^{-1}$ ) of 1-MCP (Smart Fresh; Rohm \& Hass, Vicenza, Italy). The various concentrations of 100,250 , and $500 \mathrm{~nL} \cdot \mathrm{L}^{-1} \mathrm{l}-\mathrm{MCP}$ were generated by dissolving 40,100 , and 200 $\mathrm{mg}$ of powder in various amounts of 1,2 , and $4 \mathrm{~mL}$ of warm water $\left(40^{\circ} \mathrm{C}\right)$ according to the manufacturers instructions. Afterward, the tanks were ventilated, and the fruit were stored at $10{ }^{\circ} \mathrm{C}$. 1-MCP was supplied as a commercial powder with $0.14 \%$ active compound, and was a gift from RIMI Chemicals (Petach Tikva, Israel).

TAste scores. After storage and simulated shelf life, the fruit were tasted by 10 trained panelists from the department of postharvest storage of fresh produce at the ARO, The Volcani Center. Taste was scored on a scale of 0 to 10 , where $0=$ objectionable taste and $10=$ excellent taste. Fruit taste was rated "unacceptable" when the taste score was below 6 . The fruit were served as cut segments collected from five different fruit in each treatment.

\section{Results}

Physiological characterIZATION OF FRUIT RIPENING. TO COMpare the ripening process and climacteric behaviors of the traditional white guava variety Ben Dov with those of the new varieties, the red-flesh King and the white/yellowish flesh Omri, we harvested fruit at the light-green stage, kept them at a constant temperature of $20^{\circ} \mathrm{C}$, and monitored the physiological changes that occurred during ripening. Figure 1 shows that at the day of harvest, the $\mathrm{CO}_{2}$ respiration rates of Ben Dov, King, and Omri were 65, 47, and $31 \mathrm{mg} \cdot \mathrm{kg}^{-1} \cdot \mathrm{h}^{-1}$, respectively. For all varieties, respiration rates somewhat decreased after $\mathrm{l} \mathrm{d}$ at $20^{\circ} \mathrm{C}$, but they subsequently increased: remarkably in 'Ben Dov', moderately in 'King', and hardly at all in 'Omri' fruit (Fig. 1). In 'Ben Dov', we observed a marked increase in respiration after 5 to $8 \mathrm{~d}$, which peaked at the high level of $92 \mathrm{mg} \cdot \mathrm{kg}^{-1} \cdot \mathrm{h}^{-1} \mathrm{CO}_{2}$; in 'King', we observed a moderate increase after 8 to $10 \mathrm{~d}$, which peaked at the moderate level of $58 \mathrm{mg} \cdot \mathrm{kg}^{-1} \cdot \mathrm{h}^{-1} \mathrm{CO}_{2}$; and in 'Omri', we did not observe any significant increase in respiration rates compared with the levels measured on the day of harvest (Fig. 1).

Ethylene production rates on the day of harvest were $2.2 \mu \mathrm{L} \cdot \mathrm{kg}^{-1} \cdot \mathrm{h}^{-1}$ for 'Ben Dov' fruit and just 

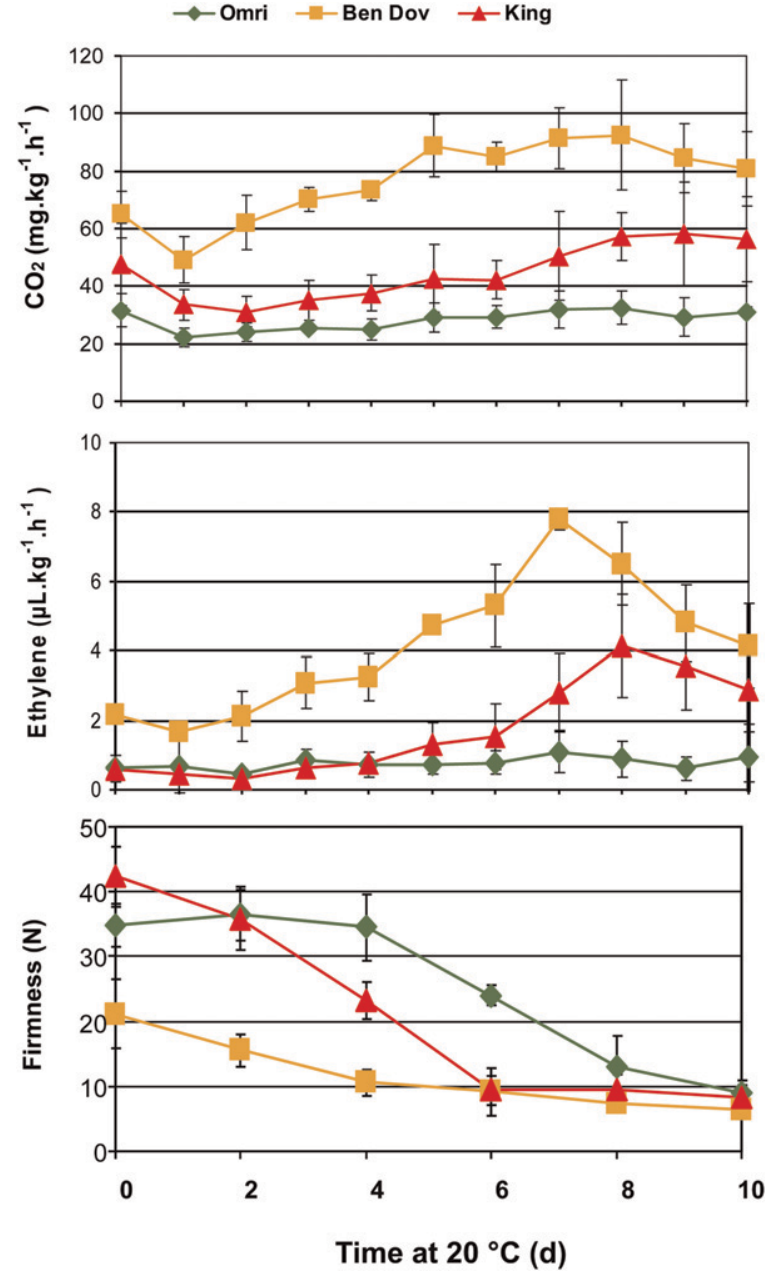

Fig. 1. Changes in respiration [carbon dioxide $\left(\mathrm{CO}_{2}\right)$ ], ethylene production, and firmness of three guava varieties (Omri, Ben Dov, and King) during postharvest ripening. Fruit were harvested at the light-green stage and kept at a constant temperature of $20^{\circ} \mathrm{C}\left(68.0^{\circ} \mathrm{F}\right)$. Data are means \pm SE of five measurements, and are from one out of three experiments with similar results; $1 \mathrm{mg} \cdot \mathrm{kg}^{-1}=1 \mathrm{ppm}$, $1 \mu \mathrm{L} \cdot \mathrm{kg}^{-1}=0.0554 \mathrm{inch}^{3} /$ ton, $1 \mathrm{~N}=0.2248 \mathrm{lbf}$.

$0.6 \mu \mathrm{L} \cdot \mathrm{kg}^{-1} \cdot \mathrm{h}^{-1}$ for 'King' and 'Omri' (Fig. 1). In 'Ben Dov', ethylene production began to increase above the levels at harvest on the third day, and reached a high peak of $7.8 \mu \mathrm{L} \cdot \mathrm{kg}^{-1} \cdot \mathrm{h}^{-1}$ after $7 \mathrm{~d}$; in 'King', it began to increase after $5 \mathrm{~d}$ and reached a peak of $4.1 \mu \mathrm{L} \cdot \mathrm{kg}^{-1} \cdot \mathrm{h}^{-1}$ after $8 \mathrm{~d}$; and in 'Omri', ethylene production rates remained constant and low, and never increased above $1 \mu \mathrm{L} \cdot \mathrm{kg}^{-1} \cdot \mathrm{h}^{-1}$ (Fig. 1).

Analysis of fruit softening revealed that 'King' and 'Omri' were already much firmer than 'Ben Dov' on the day of harvest: fruit firmness levels at harvest time were 21,42 , and $35 \mathrm{~N}$ for 'Ben Dov', 'King', and 'Omri', respectively (Fig. 1). Furthermore, 'Ben Dov' fruit softened rapidly during the first $4 \mathrm{~d}$ after harvest; 'King' fruit continued softening from day zero until $6 \mathrm{~d}$ after harvest; and 'Omri' fruit softened only from 6 through $10 \mathrm{~d}$ after harvest (Fig. 1). Nevertheless, all varieties softened to almost the same degree after the 10-d ripening period (Fig. 1). The firmness limit for salability is above $8 \mathrm{~N}$.

Overall, characterization of the physiological behavior of the various guava varieties during ripening indicated that 'Ben Dov' fruit exhibited classical climacteric type behavior, i.e., they maintained marked increases in respiration and ethylene production rates during ripening; 'King' fruit exhibited suppressed-climacteric behavior (i.e., they maintained moderate increases in respiration and ethylene production rates during the later stages of ripening); and 'Omri' fruit exhibited nonclimacteric behavior (i.e., they did not maintain any increases in respiration and ethylene production rates during ripening) (Fig. 1).

Differential RESPONSIVENESS To 1-MCP. To evaluate the responsiveness of the climacteric ('Ben Dov'), suppressed-climacteric ('King'), and nonclimacteric ('Omri') guava varieties to the ethylene-action inhibitor, 1-MCP, we exposed fruit to 1-MCP concentrations of $0,100,250$, and $500 \mathrm{~nL} \cdot \mathrm{L}^{-1}$ for $16 \mathrm{~h}$ and afterward kept them in cold storage at $10{ }^{\circ} \mathrm{C}$ for $10 \mathrm{~d}$ followed by $3 \mathrm{~d}$ at shelf life conditions at $20^{\circ} \mathrm{C}$, to simulate commercial marketing conditions. The external appearance of the fruit (Fig. 2) shows that in 'Ben Dov', the high 1-MCP concentration of 500 $\mathrm{nL} \cdot \mathrm{L}^{-1}$ was required to inhibit fruit color change; in 'King', a moderate l-MCP concentration of $250 \mathrm{~nL} \cdot \mathrm{L}^{-1}$ was enough to retard peel color change; and in 'Omri', even the lowest 1-MCP concentration of 100 $n L \cdot L^{-1}$ was sufficient to inhibit yellowing. Similarly, examination of the internal appearance of the fruit (Fig. 3 ) shows that in 'Ben Dov', the high l-MCP concentration of $500 \mathrm{~nL} \cdot \mathrm{L}^{-1}$ was required to prevent gel formation in the seed cavity; in 'King', a moderate 1-MCP concentration of 250 $\mathrm{nL} \cdot \mathrm{L}^{-1}$ was enough to retard gel formation; and in 'Omri', the lowest 1MCP concentration of $100 \mathrm{~nL} \cdot \mathrm{L}^{-1}$ was sufficient.

The described effects of the various l-MCP concentrations on the external color of the fruit were further confirmed by measuring their hue angles (Fig. 4). Furthermore, exposure to various concentrations of 1-MCP also had differing effects on fruit firmness: in 'Ben Dov', firmness levels were very low, between 4.3 and $6.4 \mathrm{~N}$, at $\mathrm{l}-\mathrm{MCP}$ concentrations of 0 to $250 \mathrm{~nL} \cdot \mathrm{L}^{-1}$, but retained higher $(9.3 \mathrm{~N})$ following exposure to the highest 1-MCP concentration of $500 \mathrm{~nL} \cdot \mathrm{L}^{-1}$ (Fig. 4). In 'King', exposure to the lowest 1-MCP concentration of $100 \mathrm{~nL} \cdot \mathrm{L}^{-1}$ had just a slight effect on fruit firmness, but exposure to the moderate $1-\mathrm{MCP}$ level of $250 \mathrm{~nL} \cdot \mathrm{L}^{-1}$ retained firmness remarkably, from a low level of $7 \mathrm{~N}$ without 1-MCP to $32 \mathrm{~N}$ (Fig. 4). In 'Omri', the lowest 1-MCP concentration of $100 \mathrm{~nL} \cdot \mathrm{L}^{-1}$ was sufficient to retained fruit firmness from a very low level of $7 \mathrm{~N}$ in control fruit, to $35 \mathrm{~N}$ (Fig. 4). 
1-MCP concentration (nL· $\left.\mathrm{L}^{-1}\right)$

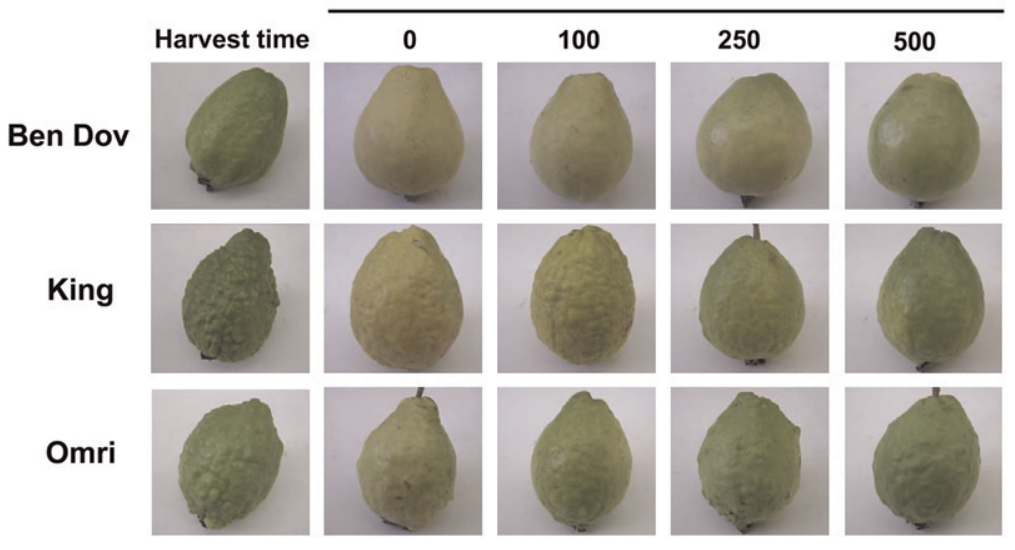

Fig. 2. Effects of various concentrations of 1-methylcyclopropene (1-MCP) on the external appearance of three guava varieties (Ben Dov, King, and Omri). Fruit were harvested at the light-green stage and exposed to 1-MCP concentrations of $0,100,250$, or $500 \mathrm{~nL} \cdot \mathrm{L}^{-1}$ for $16 \mathrm{~h}$. Pictures were taken after $10 \mathrm{~d}$ of storage at $10{ }^{\circ} \mathrm{C}\left(50.0^{\circ} \mathrm{F}\right)$ followed by $3 \mathrm{~d}$ at $20^{\circ} \mathrm{C}\left(68.0^{\circ} \mathrm{F}\right)$. The left-hand lane shows the appearance of the fruit on the day of harvest; $1 \mathrm{~nL} \cdot \mathrm{L}^{-1}=1 \mathrm{ppb}$.

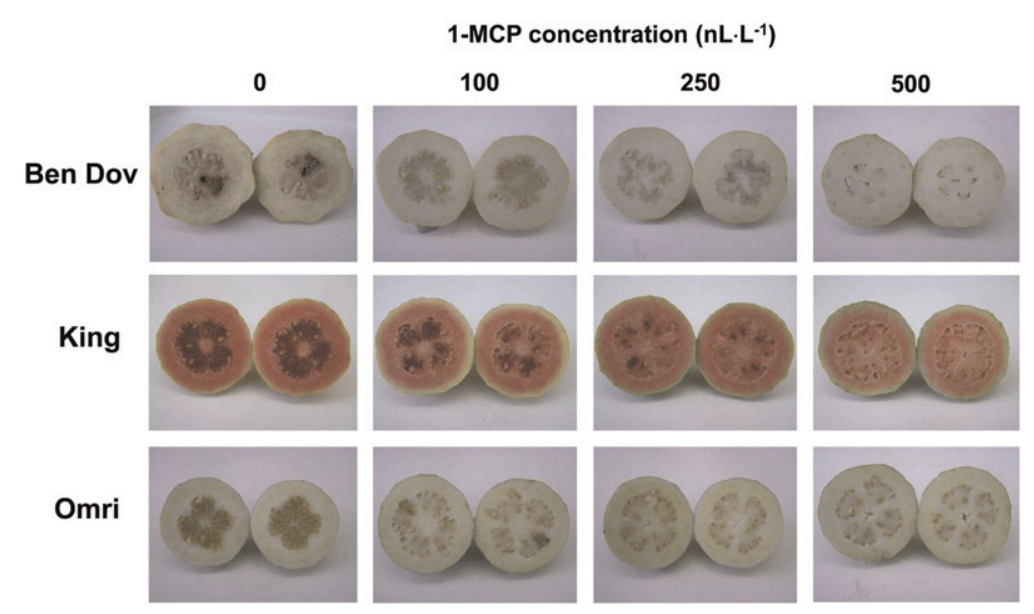

Fig. 3. Effects of various concentrations of 1-methylcyclopropene (1-MCP) on the internal appearance of three guava varieties (Ben Dov, King, and Omri). Fruit were harvested at the light-green stage and exposed to 1-MCP concentrations of $0,100,250$, or $500 \mathrm{~nL} \cdot \mathrm{L}^{-1}$ for $16 \mathrm{~h}$. Pictures were taken after $10 \mathrm{~d}$ of storage at $10{ }^{\circ} \mathrm{C}\left(50.0{ }^{\circ} \mathrm{F}\right)$ followed by $3 \mathrm{~d}$ at $20^{\circ} \mathrm{C}\left(68.0{ }^{\circ} \mathrm{F}\right) ; 1 \mathrm{~nL} \cdot \mathrm{L}^{-1}=1 \mathrm{ppb}$.

Finally, evaluation of fruit taste after $10 \mathrm{~d}$ of cold storage at $10{ }^{\circ} \mathrm{C}$ followed by $3 \mathrm{~d}$ at $20^{\circ} \mathrm{C}$ revealed that 'Ben Dov' fruit were unacceptable for eating (taste scores below 6) if not treated with the highl-MCP concentration of $500 \mathrm{~nL} \cdot \mathrm{L}^{-1}$. In contrast, 'King' and 'Omri' fruit were acceptable in all cases, but exposure to 1-MCP slightly decelerated loss in organoleptic properties (Fig. 4).

\section{Discussion}

It is well known that ethylene plays a major role in governing the ripening of guava fruit (Reyes and Paull, 1995) and, therefore, the climacteric nature of each variety is critical in determining its potential postharvest longevity. Most guava varieties characterized to date exhibit a classical climacteric behavior (Brown and Wills, 1983; MercadoSilva et al., 1998; Singh and Pal, 2008a). However, some varieties were also reported to be nonclimacteric or to have an unusual suppressedclimacteric behavior (Azzolini et al., 2005; Baile and Barcus, 1970). In the present study, we found that two new guava varieties, the red-flesh variety King and the white/yellowish-flesh variety Omri, selected during a breeding program that aimed to develop new varieties that emit fewer odors (Zipori et al., 2006), appeared to have suppressed-climacteric and nonclimacteric natures, respectively. Furthermore, these two new varieties appeared to have better postharvest storage lives than the climacteric 'Ben Dov', the commercial variety traditionally grown in Israel. For example, during ripening at $20^{\circ} \mathrm{C}$, the classical climacteric Ben Dov, the suppressedclimacteric King, and the nonclimacteric Omri varieties became soft (i.e., firmness levels below $12.5 \mathrm{~N}$ ) after 4 , 6 , and $8 \mathrm{~d}$, respectively (Fig. 1). Furthermore, after $10 \mathrm{~d}$ of storage at $10{ }^{\circ} \mathrm{C}$ followed by $3 \mathrm{~d}$ of shelf life conditions at $20{ }^{\circ} \mathrm{C}$ the climacterictype 'Ben Dov' fruit were unacceptable for consumption, i.e., taste scores below 6, whereas fruit of the suppressed-climacteric and nonclimacteric varieties remained edible (Fig. 4).

It was previously reported that exposure to 1-MCP delayed ripening of guava fruit. However, the exact concentration and duration of the 1 MCP treatment are crucial because too-high concentrations of 1-MCP completely blocked the ripening process and the fruit remained inedible (Bassetto et al., 2005), whereas too-low concentrations were not effective (Singh and Pal, 2008b). In the present study, we showed that the 1-MCP concentration required for delaying ripening and prolonging postharvest storage longevity of guava fruit depended on the climacteric nature of each variety: a high 1-MCP concentration of $500 \mathrm{~nL} \cdot \mathrm{L}^{-1}$ was required to delay ripening of the climacteric-type 'Ben Dov'; a moderate concentration of $250 \mathrm{~nL} \cdot \mathrm{L}^{-1} \mathrm{sig}$ nificantly inhibited ripening of the suppressed-climacteric 'King'; and a low concentration of just $100 \mathrm{~nL} \cdot \mathrm{L}^{-1}$ was sufficient to inhibit ripening of the nonclimacteric 'Omri' (Figs. 2-4). These findings are also consistent with the findings of previous studies, i.e., that exposure to a high 1-MCP concentration of $600 \mathrm{~nL} \cdot \mathrm{L}^{-1}$ for 12 to $24 \mathrm{~h}$ was recommended to delay ripening in 'Allahabad Safeda', a climacteric-type guava variety from India (Singh and Pal, 2008b), whereas exposure to a lower, moderate 1-MCP concentration of $300 \mathrm{~nL} \cdot \mathrm{L}^{-1}$ for 6 to $12 \mathrm{~h}$ was recommended to prolong the shelf life of 'Pedro Sato', a redpulp variety common in Brazil, that 

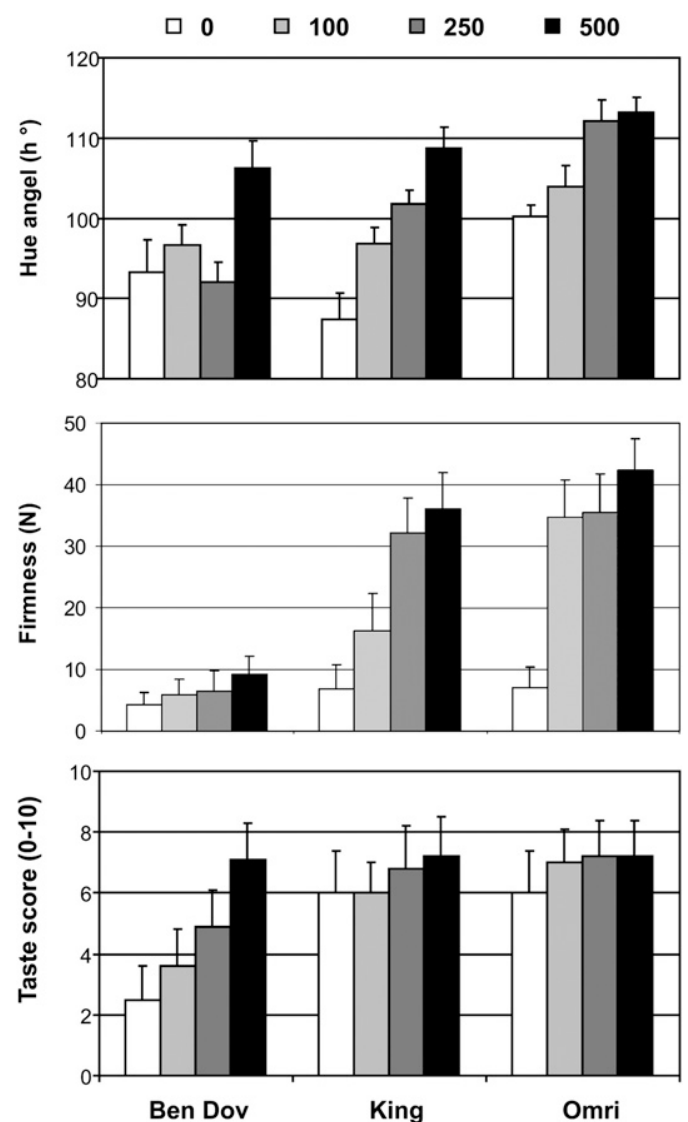

Fig. 4. Effects of various concentrations of 1-methylcyclopropene (1-MCP) on fruit color, firmness, and taste of three guava varieties (Ben Dov, King, and Omri). The fruit were harvested at the light-green stage and exposed to 1 -MCP concentrations of $0,100,250$, or $500 \mathrm{~nL} \cdot \mathrm{L}^{-1}(\mathrm{ppb})$ for $16 \mathrm{~h}$. Measurement were taken after $10 \mathrm{~d}$ of storage at $10^{\circ} \mathrm{C}\left(50.0^{\circ} \mathrm{F}\right)$ followed by $3 \mathrm{~d}$ at $20^{\circ} \mathrm{C}\left(68.0^{\circ} \mathrm{F}\right)$. Data are means $\pm \mathrm{SE}$ of 10 replications, and are from one out of three experiments with similar results. Taste was scored on a scale of 0 to 10 , where $0=$ objectionable taste and $10=$ excellent taste; $1 \mathrm{~N}=0.2248$ lbf.

has a suppressed-climacteric nature (Bassetto et al., 2005). Similar findings regarding the effects of the climacteric nature of the fruit on its responsiveness to 1-MCP were reported also for plums: in climacteric 'Santa Rosa' plum, the effects of 1-MCP were dose-dependent in the 1-MCP concentration range of 250 to $750 \mathrm{~nL} \cdot \mathrm{L}^{-1}$, whereas in the nonclimacteric 'Golden Japan' plums, even the lowest 1-MCP concentration of $250 \mathrm{~nL} \cdot \mathrm{L}^{-1}$ was sufficient to suppress ripening (MartinezRomero et al., 2003).

Overall, in the present study, we showed that different guava varieties may exhibit distinct climacteric behaviors, which affect their natural postharvest longevity and their responsiveness to 1-MCP. In future breeding programs, we suggest selecting new varieties that have suppressed-climacteric or, better still, nonclimacteric varieties because they will have superior postharvest storage lives and be more suitable for commercial marketing.

\section{Literature cited}

Abdi, N., P. Holford, W.B. McGlasson, and Y. Mizrachi. 1997. Ripening behavior and responses to propylene in four cultivars of Japanese type plums. Postharvest Biol. Technol. 12:21-34.

Abdi, N., W.B. McGlasson, P. Holford, M. Williams, and Y. Mizrachi. 1998. Responses of climacteric and suppressedclimacteric plums to treatment with propylene and 1-methylcyclopropene. Postharvest Biol. Technol. 14:29-39.

Adsule, R.N. and S.S. Kadam. 1995. Guava, p. 419-433. In: D.K. Salunke and S.S. Kadam (eds.). Handbook of fruit science and technology. Production, consumption, storage, and processing. Marcell Dekker, New York.
Azzolini, M., A.P. Jacomino, I.U. Bron, R.A. Kluge, and M.A. Schivinato. 2005. Ripening of 'Pedro Sato' guava: A study on its climacteric or non-climacteric nature. Braz. J. Plant Physiol. 17:299-306.

Baile, J.B. 1964. Growth, maturation and senescence in fruit. Science 146: 880-888.

Baile, J.B. and D.E. Barcus. 1970. Respiratory patterns in tropical fruit of the Amazon basin. Trop. Sci. 12:93-104.

Barry, C.S. and J. Giovannoni. 2007. Ethylene and fruit ripening. J. Plant Growth Regul. 26:143-159.

Bashir, H.A. and A.A. Abu-Goukh. 2003. Compositional changes during guava fruit ripening. Food Chem. 80:557-563.

Bassetto, E., A.P. Jacomino, A.L. Pinheiro, and R.A. Kluge. 2005. Delay of ripening of 'Pedro Sato' guava with 1-methylcyclopropene. Postharvest Biol. Technol. 35:303-308.

Blankenship, S.M. and J.M. Dole. 2003. 1-Methylcyclopropene: A review. Postharvest Biol. Technol. 28:1-25.

Brown, B.I. and R.B.H. Wills. 1983. Postharvest changes in guava fruit with different maturity. Scientia Hot. 19:237-243.

Downs, C.G., C.J. Brady, J. Cambell, and W.B. McGlasson. 1991. Normal ripening cultivars of Pyrus serotina are either climacteric or non-climacteric. Scientia Hot. $4: 125-130$

Giovannoni, J. 2001. Molecular biology of fruit maturation and ripening. Annu. Rev. Plant Physiol. Plant Mol. Biol. 52:725-749.

Gonzales-Aguilar, G.A., M.E. TiznadoHernandez, R. Zavaleta-Gatica, and M.A. Martinez-Tellez. 2004. Methyl jasmonate treatments reduce chilling injury and activate the defense responses of guava fruit. Biochem. Biophys. Res. Commun. 313: 694-701.

Huber, D.J. 2008. Suppression of ethylene responses through application of 1methylcyclopropene: A powerful tool for elucidating ripening and senescence mechanisms in climacteric and nonclimacteric fruit and vegetables. HortScience 43:106-111.

Jain, N., K. Dhawan, S. Malhotra, and R. Singh. 2003. Biochemistry of fruit ripening of guava (Psidium guajava L.): Compositional and enzymatic changes. Plant Foods Hum. Nutr. 58:309-315.

Jimenez-Escrig, A., M. Rincon, R. Pulido, and F. Saura-Calixto. 2001. Guava fruit (Psidium guajava L.) as a new source for antioxidant dietary fiber. J. Agr. Food Chem. 49:5489-5493. 
Kader, A.A. 2002. Guava: Recommendations for maintaining postharvest quality. 3 Feb. 2009. <http://rics.ucdavis.edu/ postharvest2/Produce/ProduceFacts / Fruit/Guava.shtml>.

Lelievre, J.M., A. Latche, A. Jones, M. Bouzayen, and J.C. Pech. 1997. Ethylene and fruit ripening. Physiol. Plant. 101: 727-739

Martinez-Romero, D., E. Dupille, F. Guillen, J.M. Valverde, M. Serrano, and D. Valero. 2003. 1-Methylcyclopropene increases storability and shelf life in climacteric and non-climacteric plums. J. Agr. Food Chem. 51:4680-4686.

McGuire, R.G. 1992. Reporting of objective color measurements. HortScience 27:1254-1255.

Mercado-Silva, E., P. Benito-Bautista, and M.A. Garcia-Velasco. 1998. Fruit development, harvest index and ripening changes of guavas produced in central Mexico. Postharvest Biol. Technol. 13: $143-150$.

Morton, J. 1987. Guava, p. 356-363. In: J.F. Morton (ed.). Fruit of warm climates. Julia F. Morton, Miami, FL.

Reyes, M.U. and R.E. Paull. 1995. Effect of storage temperature and ethylene treatment on guava (Psidium guajava L.) fruit ripening. Postharvest Biol. Technol. $6: 357-365$

Singh, S.P. and R.K. Pal. 2008a. Controlled atmosphere storage of guava (Psidium guajava L.) fruit. Postharvest Biol. Technol. 47:296-306.

Singh, S.P. and R.K. Pal. 2008b. Response of climacteric-type guava (Psidium guajava L.) to postharvest treat- ment with 1-MCP. Postharvest Biol. Technol. 47:307-314.

Sisler, E.C. and M. Serek. 1997. Inhibitors of ethylene responses at the receptor level: Recent developments. Physiol. Plant. 100:577-582.

Steinhaus, M., D. Sinuco, J. Polster, C. Osorio, and P. Schieberle. 2008. Characterization of the aroma-active compounds in pink guava (Psidium guajava L.) by application of the aroma extract dilution analysis. J. Agr. Food Chem. 56:41204127.

Watkins, C.B. 2006. The use of 1-methylcyclopropene (1-MCP) on fruit and vegetables. Biotechnol. Adv. 24:389-409.

Zipori, I., S. Shuker, A. Dag, and E. Tomer. 2006. Guava breeding in Israel. Acta Hort. 735:39-47. 